MATEC Web of Conferences 22,04001 (2015)

DOI: $10.1051 /$ matec conf/ 20152204001

(C) Owned by the authors, published by EDP Sciences, 2015

\title{
Research on Safety Factor of Dam Slope of High Embankment Dam under Seismic Condition
}

\author{
Bin $\mathrm{Li}^{*} \&$ Yu Wang \\ Tianjin Port Engineering Institute Ltd. of CCCC First Harbor Engineering Company Ltd., Tianjin, China \\ Key laboratory of port geotechnical engineering, ministry of communications, PRC. Tianjin, China \\ Key laboratory of port geotechnical engineering of Tianjin, Tianjin, China \\ Ping Sun \\ Department of Geotechnical Engineering, China Institute of Water Resources and Hydropower Research, Bei- \\ jing, China
}

\begin{abstract}
With the constant development of construction technology of embankment dam, the constructed embankment dam becomes higher and higher, and the embankment dam with its height over $200 \mathrm{~m}$ will always adopt the current design criteria of embankment dam only suitable for the construction of embankment dam lower than $200 \mathrm{~m}$ in height. So the design criteria of high embankment dam shall be improved. We shall calculate the stability and safety factors of dam slope of high embankment dam under different dam height, slope ratio and different seismic intensity based on ratio of safety margin, and clarify the change rules of stability and safety factors of dam slope of high embankment dam with its height over $200 \mathrm{~m}$. We calculate the ratio of safety margin of traditional and reliable method by taking the stable, allowable and reliability index 4.2 of dam slope of high embankment dam with its height over $200 \mathrm{~m}$ as the standard value, and conduct linear regression for both. As a result, the conditions, where 1.3 is considered as the stability and safety factors of dam slope of high embankment dam with its height over $200 \mathrm{~m}$ under seismic condition and 4.2 as the allowable and reliability index, are under the same risk control level.
\end{abstract}

Keywords: high embankment dam; stability of dam slope; ratio of safety margin; safety factor

\section{INTRODUCTION}

With the constant development of construction technology of embankment dam, a series of dams, such as Nuozhadu, Shuibuya and Shuangjiangkou dam, with their height over $200 \mathrm{~m}$ have been constructed. Given the design criteria of current grinding embankment dam are only applicable to embankment dam with its height lower than $200 \mathrm{~m}$, and the current design of high embankment dam is based on the criteria for embankment dam with its height lower than $200 \mathrm{~m}$. In addition, there's no uniform safety standard in the analysis on the stability of dam slope of high embankment dam. While it is to be settled as to whether the design and construction of stability and safety factors of dam slope of high embankment dam over $200 \mathrm{~m}$ based on safety factor specified by the regular embankment dam criteria is suitable, and there is an urgent need to propose a reasonable actual design of stability and safety factors of dam slope of high embankment dam.

The anti-slippery stability and safety assessment of upstream and downstream of embankment dam is a key technical subject ${ }^{[1-4]}$ in the engineering design and construction of embankment dam. As specified by the current design criteria for grinding embank- ment dam (SL274-2001), the non-linear intensity index shall be used for the analysis on body stability of embankment dam, and small average value for shearing strength index; the stability and safety factor of dam slope of embankment dam in Rank I shall be over 1.5 under normal working conditions, and over 1.2 under seismic condition; as specified by the common standard (GB50199_-94) of structural reliability design for water-power engineering, 4.2 is considered as the allowable and reliability index for the dams in Rank I subject to Class-II destruction, and $1.33 \times 10^{-5}$ as the corresponding invalidation probability. The invalidation probability of stability of dam slope of embankment dam with its height over $200 \mathrm{~m}$ shall not be higher than $1.33 \times 10^{-5}$, the invalidation probability of stability of dam slope of embankment dam with its height lower than $200 \mathrm{~m}$, namely the stable, allowable and reliability index of dam slope over $200 \mathrm{~m}$ shall not be lower than 4.2 .

This paper uses non-linear intensity index to calculate the safety factor and reliability index for the stability model of dam slope of high embankment dam under normal and seismic condition ${ }^{[5-7]}$, and determine the stability and safety factor of dam slope of embankment dam with its height over $200 \mathrm{~m}$ based on the theory ${ }^{[7-8]}$ of ratio of safety margin and by comparing the corresponding ratio of safety margins for both.

*Corresponding author: lee binbin@163.com

This is an Open Access article distributed under the terms of the Creative Commons Attribution License 4.0, which permits unrestricted use, distribution, and reproduction in any medium, provided the original work is properly cited. 


\section{MATEC Web of Conferences}

\section{ANALYSIS ON THE STABILITY OF DAM SLOPE OF ROCK-FILL DAM}

Duncan logarithm non-linear model ${ }^{[3-4]}$ is used in the stone stack parameters in calculating the stability of dam slope of rock-fill dam, and the intensity indexes $\phi_{0}$ and $\Delta \phi$ of stone stack are used in the calculation. Once standard deviation is subtracted based on the statistic average of constructed domestic project; we use circular slip surface and Bishop Method to calculate the stability and safety factor of dam slope, and see Figure 1 for the abbreviated drawing of calculation.

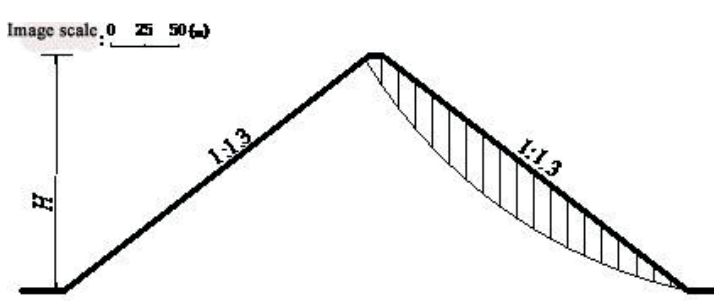

Figure 1. Abbreviated drawing of calculation for embankment dam with its dam slope in 1:1.3

\subsection{Effect of dam slope ratio on the safety factor}

To make research on the stability feature of dam slope of embankment dam with its height over $200 \mathrm{~m}$, we select a dam model in height of $300 \mathrm{~m}$, use the dam slope 1:1.4 for the upstream of dam body, and 1:1.3, $1: 1.4,1: 1.5$ respectively for the downstream. We calculate the stability and safety factor of dam slope according to the affirmative method to clarify the change rule of safety factor. Select completion date as the calculation working conditions (no water in upstream or downstream); the intensity index parameters are shown in Table 1; the calculation result of stability and safety factor of dam slope is shown in Table 2 .

It can be found from the calculation result of analysis on the stability of model dam slope that:

Under different dam slopes, the stability and safety factor of high dam slope of embankment dam with its height of $300 \mathrm{~m}$ can partially meet the standard value 1.5 in the current specification requirement; the stability and safety factor of dam slope tends to increasingly slow down with the dam slope of dam slope. It is recommended to properly increase the dam slope for the high embankment dam project with its height over $200 \mathrm{~m}$ in order to increase the safety factor.

\subsection{Effect of seismic intensity on the safety factor}

Take the embankment dam with its height of $150 \mathrm{~m}$, $200 \mathrm{~m}, 250 \mathrm{~m}, 300 \mathrm{~m}$ and $350 \mathrm{~m}$, dam slope in ratio of $1: 1.3,1: 1.4$ and $1: 1.5$ as the research objective, and use the affirmative model to analyze the stability and safety factor of dam slope. The calculation working conditions focus on the seismic condition suffered in the downstream slope, and the seismic load is simulated by quasi-static method ${ }^{[5-7]}$. The calculation result is shown in Table 3.

Table 1. Model calculation parameters

\begin{tabular}{|c|c|c|c|c|}
\hline Parameters & $\phi_{0}\left({ }^{\circ}\right)$ & & $\Delta \phi\left({ }^{\circ}\right)$ & \\
\hline Name of material & $\begin{array}{l}\text { Standard devia- } \\
\text { tion }\end{array}$ & Small average value & $\begin{array}{l}\text { Standard devia- } \\
\text { tion }\end{array}$ & Small average value \\
\hline Upstream stone stack & 2.0 & 51.0 & 1.0 & 11.0 \\
\hline $\begin{array}{l}\text { Downstream stone } \\
\text { stack }\end{array}$ & 2.0 & 49.0 & 1.3 & 10.1 \\
\hline
\end{tabular}

Table 2. Calculation of the stability and safety factor of dam slope with different dam slopes

\begin{tabular}{lll}
\hline Slope position & Model slope ratio & Calculating the safety factor \\
\hline Upstream dam slope & Upstream slope 1:1.4 Downstream slope 1:1.3 & 1.405 \\
& & \\
& Upstream slope 1:1.4 Downstream slope 1:1.4 & 1.475 \\
& Upstream slope 1:1.4 Downstream slope 1:1.5 & 1.502 \\
Downstream dam slope & Upstream slope 1:1.4 Downstream slope 1:1.3 & 1.416 \\
& & 1.522 \\
& Upstream slope 1:1.4 Downstream slope 1:1.4 & 1.628 \\
\hline
\end{tabular}

Table 3. Calculation of the stability and safety factor of seismic intensity with different dam slopes

\begin{tabular}{llllllll}
\hline $\begin{array}{l}\text { Dam } \\
\text { height }\end{array}$ & \multicolumn{2}{l}{ Seismic intensity 7 degree } & \multicolumn{3}{c}{ Seismic intensity 8 degree } & \multicolumn{3}{c}{ Seismic intensity 9 degree } \\
\hline Dam slope & $1: 1.4$ & $1: 1.5$ & $1: 1.3$ & $1: 1.4$ & $1: 1.5$ & $1: 1.4$ & $1: 1.5$ \\
150 & 1.503 & 1.583 & 1.374 & 1.421 & 1.496 & 1.283 & 1.357 \\
200 & 1.459 & 1.542 & 1.325 & 1.406 & 1.447 & 1.250 & 1.303 \\
250 & 1.412 & 1.478 & 1.284 & 1.352 & 1.436 & 1.209 & 1.255 \\
300 & 1.364 & 1.437 & 1.245 & 1.304 & 1.352 & 1.166 & 1.233 \\
350 & 1.329 & 1.398 & 1.202 & 1.274 & 1.327 & 1.138 & 1.213 \\
\hline
\end{tabular}


It is found from the calculation result that:

When the dam slopes with the same slope ratio also have the same seismic intensity, the stability and safety factor of dam slope corresponding to the increase of dam height will be reduced. When the dam slopes with the same dam height also have the same seismic intensity, the stability and safety factor of dam slope corresponding to the increase of slope ratio will be reduced; when the dam slopes have the same dam height and dam slope, the stability and safety factor of dam slope corresponding to the increase of seismic intensity will be reduced. If the seismic intensity is in 8 degree, the dam height of $300 \mathrm{~m}$ and slope ratio of $1: 1.3$ can meet the requirement of stability and safety factor of dam slope specified in the current design criteria of embankment dam. If the seismic intensity is in 9 degree, only the slope ratio of dam slope with its height of $300 \mathrm{~m}$ that reaches $1: 1.3$ can meet the criteria and requirement.

With the increase of dam height, the non-linear feature of intensity index of dam body material leads to the decrease of overall intensity index along the slip surface of dam material, and the properly slowing down the dam slope is one of the method to ensure the anti-slippery stability of dam slope of high embankment dam meets the criteria and requirement. It can be found from the calculation analysis on the model dam that the stability and safety factor of dam slope of embankment dam with its height of $300 \mathrm{~m}$ meets the general rules. As the dam height of dam slope $(1: 1.3$ and $1: 1.4)$ regularly designed hits $300 \mathrm{~m}$, the anti-slippery stability and safety factor of dam slope of high embankment dam cannot meet the criteria and requirement, so we shall reconsider the value of anti-slippery stability and safety factor of dam slope of high embankment dam.

3 RESEARCH ON THE STABILITY AND SAFETY FACTOR OF DAM SLOPE OF EMBANKMENT DAM WITH ITS HEIGHT OVER $200 \mathrm{M}$

There's no widely recognized allowable and reliability index [5] for the high embankment dam with its height over $200 \mathrm{~m}$, but the invalidation probability of high embankment dam shall not exceed that for current embankment dam with its height of $200 \mathrm{~m}$. So 4.2 is taken as the allowable reliability index of anti-slippery stability of dam slope of high embankment dam with its height over $200 \mathrm{~m}$. According to this allowable and reliability index standard, this article makes research on the stability and safety factor of dam slope of high embankment dam, and verifies the correctness and reasonableness of the proposed standard.

\subsection{Basic theory of the ratio of safety margin}

The ratio of safety margin proposed by China Institute of Water Resources and Hydropower Research is an index[8-9] to measure the safety standard of a given building with respect to the margin width of required standard. The calculation formulas for the ratio of safety margin $\eta_{R}$ of definition reliability method and $\eta_{F}$ of traditional safety factor method are as follows:

$\eta_{R}=\left(\beta-\beta_{a}\right) \sigma_{F}+1$

$\eta_{F}=\frac{F}{F_{a}}$

Based on the specified reasonable allowable safety factor $F_{a}$, the ratio of safety margin $\eta_{R}$ of reliability method has a good ability to allude to $\eta_{F}$.

\subsection{Calculation of the ratio of safety margin}

This research focuses on the dam slope ratio of $1: 1.3$ and 1:1.4, with fixed width of dam top and dam slope of upstream and downstream; then compare the ratio of safety margin $\eta_{F}$ and $\eta_{R}$ in case of different dam height $\mathrm{H}$, in order to confirm the universal applicability of above conclusions. The upstream stone stack parameters in Table 1 will be used for the non-linear shearing strength index of dam construction material, and the abbreviated drawing of calculation is shown in Figure 1.

Consider the seismic intensity as 8 degree, standard value of anti-slippery stability and safety factor as $\mathrm{Fa}=1.2$, allowable and reliability index $\beta \mathrm{a}=4.2$ as the standard value under seismic condition for Rank I embankment dam to calculate the ratio of safety margin of stability of dam slope of embankment dam.

\subsubsection{Typical calculation examples 1:1.3 embank- ment dam}

In case the seismic conditions exceed the probability and in case of different dam height, see Table 4 of calculation result for the affirmative model and reliability analysis under 8 degree of seismic condition in this typical calculation examples for embankment dam according to the criteria and requirement $F_{a}=1.2, \beta_{a}=4.2$. See Figure 2 for the interrelationship of the ratio of safety margin $\eta_{F}$ and $\eta_{R}$

By reviewing the calculation result of maximum dam height $\mathrm{H}=200 \mathrm{~m}$, we can see the safety factor of affirmative model F=1.325, slightly exceeding $F_{a}=1.2$ in the criteria and requirement; the reliability index $\beta=4.402$ calculated by reliability analysis method is also slightly more than $\beta_{a}=4.2$ in the criteria and requirement. So the criteria requirements on $F_{a}$ and $\beta_{a}$ are basically in the same safety level.

By reviewing the Figure 2 under different dam height $\mathrm{H}$, the ratio of safety margin $\eta_{F}$ and $\eta_{R}$ of this calculation example are basically equal to each other, and the fitting factor $a=0.9378$, slightly less than 1 , indicating the standard value of safety factor under seismic condition has a slightly lower safety level. As for the standard value of stability and safety factor of dam slope under seismic condition of high embankment dam with its height over $200 \mathrm{~m}$, we shall first calculate the ratio of safety margin of traditional method of different standard value of safety factor to fit the ratio of safety margin of reliability method with allowable and reliability index 4.2 , then check the fitting gradient before confirmation. 


\section{MATEC Web of Conferences}

Table 4. Calculation results of stability of dam slope of embankment dam in 1:1.3 (in 8 degree of seismic conditions)

\begin{tabular}{lllll}
\hline \multirow{2}{*}{ Dam height } & \multicolumn{2}{c}{ Affirmative model } & \multicolumn{2}{c}{ Reliability analysis } \\
\cline { 2 - 5 } 75 & $F$ & $\eta_{F}$ & 6.372 & 1.216 \\
100 & 1.5 & 1.283 & 5.959 & 1.143 \\
125 & 1.458 & 1.215 & 5.369 & 1.112 \\
150 & 1.427 & 1.190 & 5.091 & 1.074 \\
175 & 1.374 & 1.145 & 4.813 & 1.045 \\
200 & 1.343 & 1.119 & 4.402 & 1.025 \\
\hline
\end{tabular}

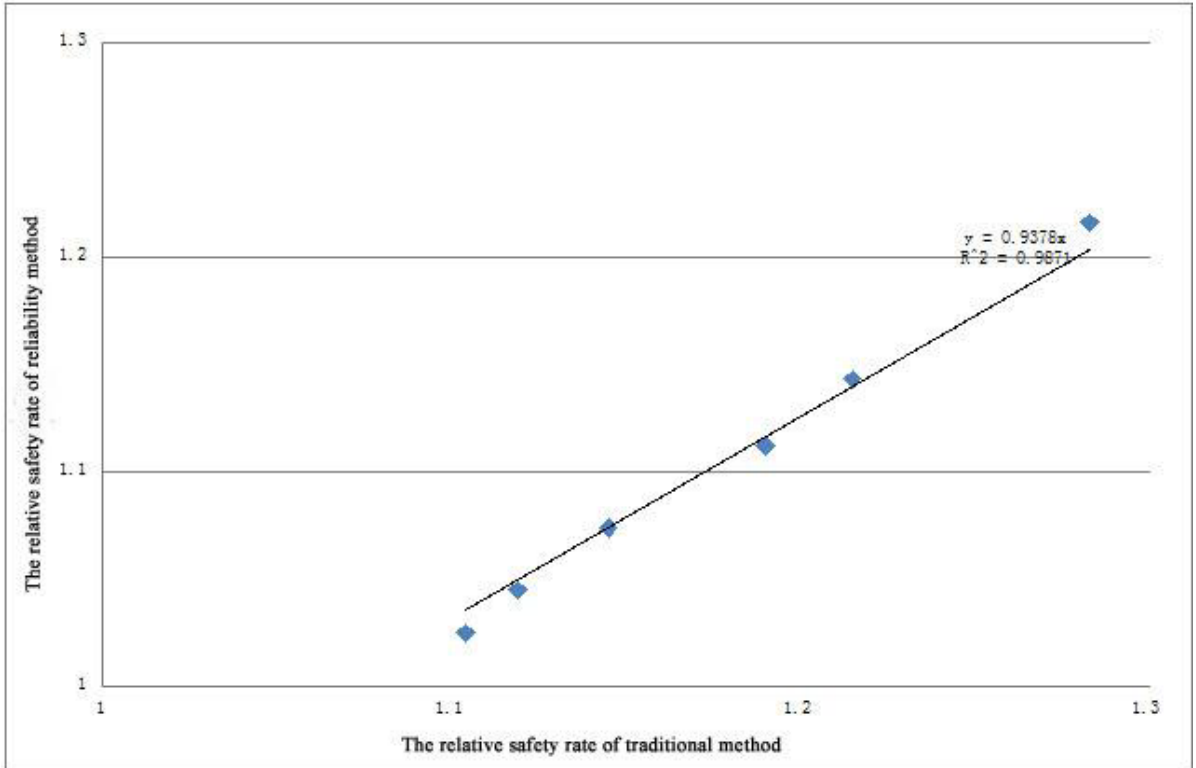

Figure 2. Interrelationship between $\eta_{F}$ and $\eta_{R}$ under seismic condition of dam slope of embankment dam in 1:1.3

Table 5. Calculation results of stability of dam slope of high embankment dam in 1:1.3 (in 8 degree of seismic conditions)

\begin{tabular}{lllllll}
\hline \multirow{2}{*}{$\begin{array}{l}\text { Dam } \\
\text { height }\end{array}$} & \multicolumn{2}{l}{ Affirmative model } & \multicolumn{3}{c}{ Reliability analysis } \\
\cline { 2 - 7 } 200 & 1.325 & 1.104 & 1.019 & 0.981 & 4.402 & 1.025 \\
225 & 1.285 & 1.071 & 0.988 & 0.952 & 4.200 & 1.000 \\
250 & 1.284 & 1.07 & 0.988 & 0.951 & 4.170 & 0.996 \\
275 & 1.255 & 1.046 & 0.965 & 0.93 & 3.995 & 0.974 \\
300 & 1.245 & 1.0375 & 0.958 & 0.922 & 3.929 & 0.966 \\
350 & 1.202 & 1.002 & 0.925 & 0.89 & 3.704 & 0.939 \\
\hline
\end{tabular}

Table 6. Calculation results of stability of dam slope of embankment dam in 1:1.4 (in 8 degree of seismic conditions)

\begin{tabular}{lllll}
\hline \multirow{2}{*}{ Dam height } & \multicolumn{3}{c}{ Affirmative model } & \multicolumn{3}{c}{ Reliability analysis } \\
\cline { 2 - 5 } & $F$ & $\eta_{F}$ & $\beta$ & $\eta_{R}$ \\
\hline \multirow{2}{*}{15} & 1.6 & 1.384 & 6.156 & 1.278 \\
175 & 1.499 & 1.249 & 5.348 & 1.154 \\
200 & 1.427 & 1.189 & 4.869 & 1.091 \\
\hline
\end{tabular}


ICETA 2015

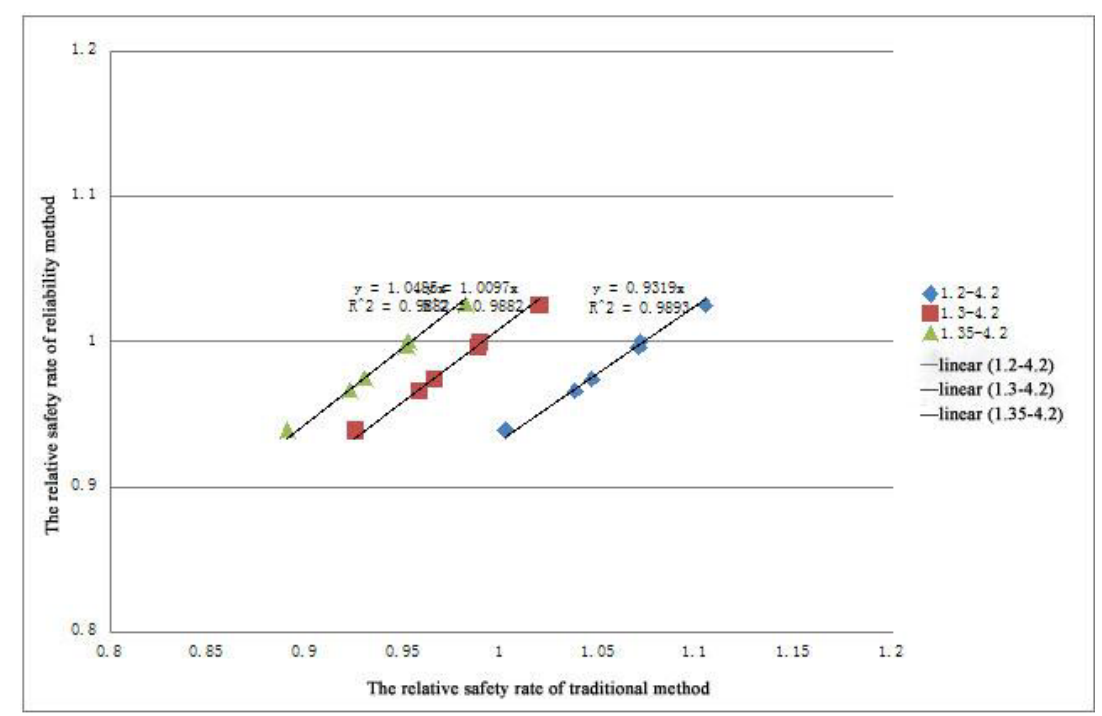

Figure 3. Interrelationship between $\eta_{F}$ and $\eta_{R}$ under seismic condition of dam slope of high embankment dam in 1:1.3

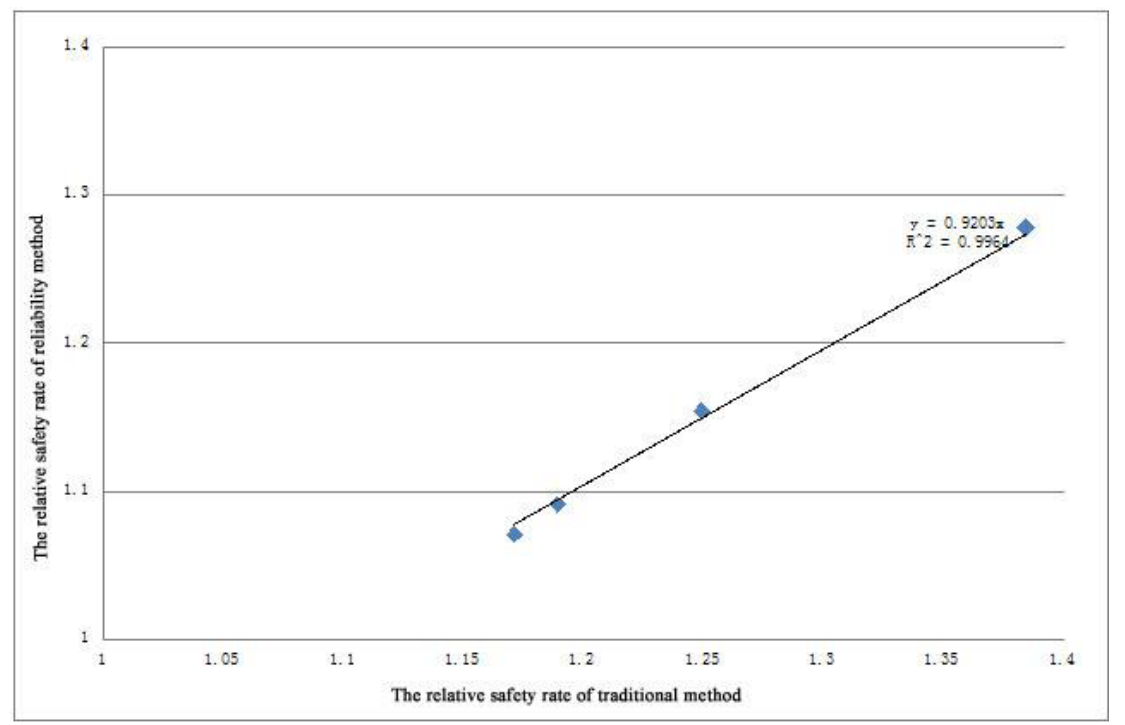

Figure 4. Interrelationship between $\eta F$ and $\eta \mathrm{R}$ under seismic condition of dam slope of embankment dam in 1:1.4

Table 7. Calculation results of stability of dam slope of high embankment dam in 1:1.3 (in 8 degree of seismic conditions)

\begin{tabular}{lllllll}
\hline \multirow{2}{*}{ Dam height } & & \multicolumn{3}{c}{ Affirmative model } & \multicolumn{3}{c}{ Reliability analysis } \\
& $F$ & $\eta_{F 1.2}$ & $\eta_{F 1.3}$ & $\eta_{F 1.35}$ & $\beta$ & $\eta_{R}$ \\
\hline 200 & 1.406 & 1.171 & 1.082 & 1.041 & 4.713 & 1.071 \\
225 & 1.364 & 1.136 & 1.049 & 1.01 & 4.534 & 1.044 \\
250 & 1.352 & 1.127 & 1.04 & 1.001 & 4.451 & 1.033 \\
275 & 1.332 & 1.110 & 1.025 & 0.987 & 4.317 & 1.016 \\
300 & 1.304 & 1.087 & 1.003 & 0.966 & 4.201 & 1.000 \\
350 & 1.278 & 1.065 & 0.983 & 0.947 & 4.030 & 0.977 \\
\hline
\end{tabular}


MATEC Web of Conferences

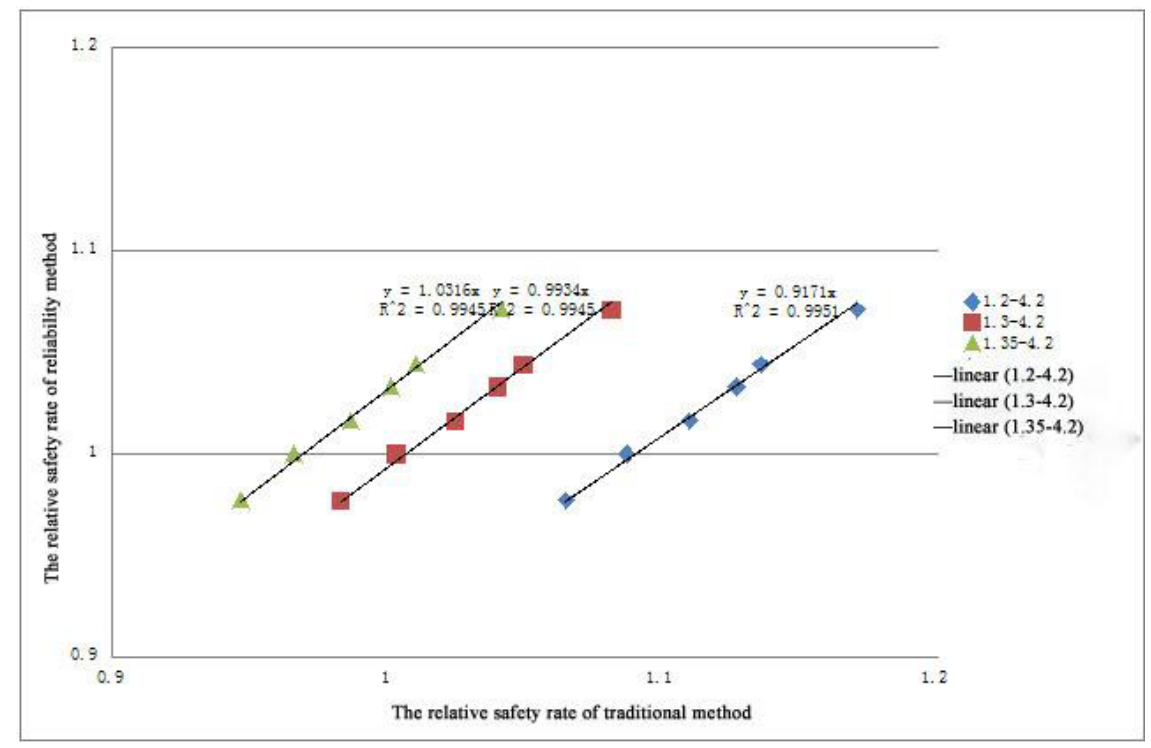

Figure 5. Interrelationship between $\eta_{F}$ and $\eta_{R}$ under seismic condition of dam slope of high embankment dam in 1:1.4

We hereby discuss the specification of allowable safety factor $\mathrm{Fa}$ of affirmative model under seismic condition in the criteria. If $F a=1.35$, see Figure 3 to compare it to $F a=1.2$ specified in the criteria.

In Figure 3, the full line represents the fitting line ${ }^{[8]}$ of $\eta_{F}$ and $\eta_{R}$ calculated by the standard value of different safety factors under seismic condition for Class-A Dam. When $F_{a}=1.3$, the fitting slope of data points $\left(\eta_{F}, \eta_{R}\right)$ is 1 , indicating $F_{a}=1.3$ is more reasonable. It is known from the above analysis that: the criteria have a little less requirement on the allowable safety factor $F_{a}=1.2$ under seismic condition for Rank I embankment dam, and its reasonable value is 1.3 .

\subsubsection{Typical calculation examples 1:1.4 embank-} ment dam

See Table 6 of calculation result for the safety factor of affirmative model and reliability index under 8 degree of seismic condition in this typical calculation examples for embankment dam according to the criteria and requirement $F_{a}=1.2, \beta_{a}=4.2$. See Figure 4 for the interrelationship of ratio of safety margin $\eta_{F}$ and $\eta_{R}$.

Under different dam height $\mathrm{H}$, the ratio of safety margin $\mathrm{hF}$ and $\mathrm{hR}$ of this calculation example are basically equal to each other, and the fitting factor $\mathrm{a}=0.92$, with excellent linear relation, and the squared value of relevant factors reaches 0.996 . The safety factor and reliability index specified in the criteria can be obtained by the calculation of stability and safety factor of dam slope under seismic condition for embankment dam in 1:1.4 in typical calculation examples. The criteria have a little less requirement on the allowable safety factor $\mathrm{Fa}=1.2$ under seismic condition for Rank I embankment dam.

As for the high embankment dam, we shall calcu- late the ratio of safety margin of traditional method of different standard values of safety factor to fit the ratio of safety margin of reliability method with allowable and reliability index 4.2 , and then check the fitting gradient. The calculation result is shown in Table 7, and the fitting result is as shown in Figure 5.

It is known from Figure 5 that, the criteria requirement on the reasonable value of allowable safety factor $F_{a}$ under seismic condition for Rank I embankment dam is 1.3 .

\subsection{CONCLUSIONS}

(1) The ratio of safety margin method can put the safety factor and reliability index on the same platform. It is known either of them can be used to obtain the other by ratio of safety margin method, and both are in the same risk control level.

(2) As for the high embankment dam with its height over $200 \mathrm{~m}, 4.2$ is taken as the same allowable and reliability index for Rank I embankment dam specified in the criteria, and after calculation, we obtain the standard value of stability and safety factor $F_{a}=1.6$ for the dam slope under normal working conditions, and $F_{a}=1.3$ under seismic condition.

\section{CONCLUSION}

The stability and safety factor of dam slope of embankment dam with its height over $200 \mathrm{~m}$ meets the general rules. The dam slope with higher dam, sheerer slope and larger seismic intensity will have a less stability and safety factor. As the dam height of dam slope $(1: 1.3)$ regularly designed hits $300 \mathrm{~m}$, the anti-slippery stability and safety factor of dam slope of high embankment dam cannot meet the criteria and 
requirement.

If 4.2 is taken as the allowable reliability index of anti-slippery stability of dam slope of high embankment dam with its height over $200 \mathrm{~m}$, and the invalidation probability of stability of corresponding dam slope of high embankment dam is $1.33 \times 10^{-5}$. We can obtain, through calculation, the standard value of stability and safety factor $\mathrm{Fa}=1.6$ for the dam slope under normal working conditions, and $\mathrm{Fa}=1.3$ under seismic condition. Moreover, they are both in the same risk control level.

\section{REFERENCES}

[1] Zhang, M., Liu, J.Y. \& Mai, J.X. 2006. Analysis and design of stability and reliability of side slope on embankment dam. Hydropower Journal. 25(2): 103-107.

[2] Lu, Q.F. \& Yin, Z.Z. 2004. Effect of non-linear intensity parameters on the stability of dam slope of high embankment dam, Journal of Rock Mechanics and Engineering, 23(16): 2708-2711.

[3] Lu, Q.F. \& Yin, Z.Z. 2004. Non-linear analysis on the stability of dam slope of high embankment dam. Rock Mechanics, 25(5): 793-797.

[4] Chen, L.H. \& Chen, Z.Y. 2007. Effect of non-linear intensity feature of stone stack on the stability of high embankment dam. Rock Mechanics, 28(9): 1807-1810.

[5] Wang, X.Q., Lei, X.S. \& Chen, Z.Y. 2010. Analysis on Risk of Hydropower Project and Technical Progress of Reliability Design. Beijing: China Hydropower Press. pp: 216-222.

[6] Zhao, J.M., Liu, X.S. \& Chen, N., et al. 2009. Research on the ultimate anti-shock ability of high wall stone stack dam. Hydropower Journal, 28(5): 97-102.

[7] Xu. B., Zou, D.G., Kong, X.J., et al. 2012. Research on the analysis of seismic stability of dam slope of high embankment dam. Journal of Rock Engineering, 34(1): 139-144.

[8] Chen, Z.Y., Xu, J.C. \& Sun, P., et al. 2012. Analysis on the anti-slippery stability and reliability for gravity dam: (1) Ratio of safety margin method. Hydropower Journal, 31(3): 148-159.

[9] Chen, Z.Y., Xu, J.C. \& Chen, L.H., et al. 2012. Analysis on the anti-slippery stability and reliability for gravity dam: (2) Research on the reasonable value of intensity index and partial factor, Hydropower Journal, 31 (3) 160-1167. 